\title{
ARBITRATION OF STATE-TRADING RELATIONS
}

\section{Martin Domke*}

State-trading operations, it is widely felt, including those not completely motivated by economic considerations, should conform to world trade customs, at least in so far as the disposition of controversies is concerned. ${ }^{1}$ A reflection of this attitude can be found in the modern commercial treaties of the United States, which expressly disavow immunity in state-trading relations with respect not only to "suits" in ordinary courts, but also to arbitration. ${ }^{3}$ Thus, too, recent resolutions of the Inter-American Bar Association, ${ }^{4}$ the International Law Association, ${ }^{5}$ and the International Chamber of Commerce ${ }^{6}$ have recommended the use of arbitration for the settlement of disputes

- Dr. Jur. Utr. 1915, University of Greifswald, Germany. International Vice President and Director of Legal Research, American Arbitration Association; Editor-in-Chief of the Arbitration Journal; Adjunct Associate Professor of Law, New York University; Chairman, Committee on International Commercial Arbitration, International Law Association; Member, General Council, American Foreign Law Association; Member, Executive Committee, American Branch, International Law Association. Author, LA clsuse "DOLLAR-OR"; LA NON-APPLICATION DE LA LEGISLATION AMERICAINE AUX EMPRUNTS INTERNATIONAUX (I935), Trading with the Enemy in World War II (I943), The Control of Alien Property (ig47), Amerrcan-German Private Law Relations Cases (I956). Editor, International Trade Arbitration: A Rond to World Wide Cooperation (1958). Contributor to American and foreign legal periodicals.

${ }^{2}$ See e.g., Seidl-Hohenveldern, Commercial Arbitration and State Immunity, in MARTIN DoMke (Ed,), International Trade Arbitration: A Road to World-Wide Cooperation 87 (i958); Schmitthoff, The Claim of Sovercign Immunity in the Laws of International Trade, 7 INT'L \& CoM. L. Q. 452 (1958); Macdonald, New Method to Test Sovereign Immunity from Suit, 36 ChN. B. REv. 549 (I958). A searching discussion of the manner in and extent to which immunity from foreign jurisdiction is invoked for state-trading operations appears elsewhere in this symposium. See Setser, Sovereign Immunity and State Trading, supra $29 \mathrm{r}$.

${ }^{2}$ See, e.g., Treaty of Friendship, Commerce, and Navigation With the Republic of Korea, Nov. 28, 1956, T.I.A.S. No. 3947 (effective Nov. 7, 1957): "No enterprise of either Party, including corporations, associations, and government agencies and instrumentalities, which is publicly owned or controlled shall, if it engages in commercial, industrial, shipping or other business activities within the territories of the other Party, claim or enjoy, either for itself or for its property, immunity therein from taxation, suit, exectution of judgment or other liability to which privately owned or controlled enterprises are subject therein." (Emphasis added.)

${ }^{3}$ Cf. Madawick Contracting Co., Inc. v. Travelers Ins. Co., 307 N.Y. III, II9, I20 N.E.2d 520, 523 (1955), where it was said: "Judgment' shall include such judgments as are entered upon confirmation of arbitration awards. ..."

"That the machinery of commercial arbitration within the Western Hemisphere should also be used for disputes between individuals and foreign governments in matters in which those governments participate directly or through their agencies and corporations in international trade." INTER-AMERICAN Bar Ass'n, Proceedings 269 (I952).

c "The International Law Association recommends the intensive development and use of international commercial arbitration for the settlement of disputes including those between Governments and agencies and Government-controlled corporations and private persons of different countries." INT'L LAW Ass's, Report OF THE Forty-Fourth CONFERENCE 264 (1950).

- "The International Chamber of Commerce recommends governments, governmental agencies and government-controlled corporations to insert in their contracts with private individuals and firms of another country an arbitration clause providing for the settlement of possible disputes by recourse to existing organizations of international commercial arbitration." INT'z ChAMBER OF COMMERCE, RESOLUTIONS of THE XIV CoNGREss 9I (Brochure No. 175, 1953). Arbitration between states and private firms was also discussed at the XVII Congress of the International Chamber of Commerce, Washington, D.C., April 21, 1959. 
arising out of contracts to which governments or their agencies are parties.

When foreign states or state-owned or controlled companies have concluded arrangements with American traders, ${ }^{8}$ especially in wartime dealings ${ }^{0}$ or in the postwar period of economic reconstruction, ${ }^{10}$ they have customarily submitted their disputes to private arbitration under the rules of the American Arbitration Association. Only once, in 1946 , has the issue of sovereign immunity in arbitration been raised in this country; and even then, it was not pursued to a final determination. ${ }^{11}$ Contracts between the United Nations and its agencies and private firms have likewise provided for dispute-settlement under the rules of private arbitration organizations; ${ }^{12}$ and in some instances, arbitration proceedings have been utilized. ${ }^{13}$ Among the foreign governmental agencies which have submitted controversies to private arbitration have been the Argentine Institute of Trade Development, ${ }^{14}$ the Turkish Railway Administration, ${ }^{15}$ and a nationalized Czechoslovakian enterprise, formerly Dynamit Nobel, now Georges Dimitrov. ${ }^{16}$ The elaborate private arbitration set-up

${ }^{7}$ The Commission on International Commercial Arbitration of the International Chamber of Commerce, the Ad-hoc Working Group on Arbitration of the Committee on the Development of Trade of the Economic Commission for Europe, see infra note 22, and the Committee on International Commercial Arbitration of the International Law Association are actually engaged in detailed studies of the problems of arbitration between governments and foreign traders. The International Institute for the Unification of Private Law in Rome, too, has established a working committee on arbitration between governments and individuals. A draft convention prepared by its chairman, Judge Algot Bagge, of Sweden, considers the possibility of conferring on the Permanent Court of Arbitration at the Hague such jurisdiction, through an agreement between states and an amendment of the Court's statute. See 3 INT'L INST. FOR the Unification of Private Law, Unification of LAw 65 (1954). This effort, however, is a general one, not specifically concerned with state-trading relations.

${ }^{8}$ Where the state, as such, is not party to the arrangement, it may be noted, "adequate opportunity for consultation" in trade controversies is, nevertheless, provided in the General Agrecment on Tariffs and Trade, Oct. 30, 1947, 6r STAT. (5), (6), T.I.A.S. No. 1700, art. XXII (effective Jan. $x$, 1948). See also Economic Agreement of Bogota of May 2, 1948 , art. 38, and the Rules of Procedure to Facilitate the Peaceful and Rapid Settlement of Economic Disputes, adopted by the Council of the League of Nations, Jan. 28, 1932, all pertinent provisions of which may be found in U.N. Doc. No. E/ECE/270, pt. II, at I-5 (1957).

See, e.g., Government of the Kingdom of The Netherlands v. American Armament Corp., 58 N.Y.S.2d 300 (Sup. Ct. 1945).

${ }^{10}$ See, e.g., Republic of France v. Ingalls Shipbuilding Corp., Civil No. 5986, N.D. Ala., March 3r, 1947, noted in 2 ARB. J. (n.s.) 264 (I947); République Française v. Cellosilk Mfg. Co., 309 N.Y. 269, 128 N.E.2d 750 (1955); American Rail and Steel Co. v. India Supply Mission (Government of India), 308 N.Y. 577, I27 N.E.2d 562 (1955), noted in 13 ARB. J. (n.s.) 33 (1958); Government of the Argentine Republic v. Gaylen Machinery Corp., ro Misc.2d 215, 169 N.Y.S.2d 978 (Sup. Ct. 1957).

${ }^{11}$ In Peter B. Payne, Ine. v. National Resources Commission of China, the defendant appeared specially in the Supreme Court of New York, County of New York, and moved to vacate a warrant of attachment, obtained under a contract for engineering services containing an arbitration clausc, on grounds of sovereign immunity. N.Y.L.J., Aug. 23, r946, p. 32r; id., Aug. 30, 1946, p. 36r. Cf. Duff Development Co., Ltd. v. Government of Kalatan, [1924] A.C. 797.

12 See 5 Repertory of Practice of United Nations Organs 332 (1955).

${ }^{13}$ E.g., by the United Nations Children's Fund, and the United Nations Korean Reconstruction Agency, under the rules of the American Arbitration Association.

It Referring to the rules of the Inter-American Commercial Arbitration Commission.

${ }^{15}$ See Turkish State Railways, Administration v. Vulcan Iron Works, 136 F. Supp. 622 (M.D. Pa. r955), appeal dismissed (as from an interlocutory decision denying a motion to compel arbitration), 230 F.2d 108 (3d Cir. 1956). See also Turkish State Railways Administration v. Vulcan Iron Works, 153 F. Supp. 6I6 (M.D. Pa. I957).

${ }^{10}$ Under the Rules of Conciliation and Arbitration of the International Chamber of Commerce. Cf. 
under both the so-called International Consortium Agreement of the National Iranian Oil Company of September $1954^{17}$ and the agreement of September 5, I957 of the same Iranian governmental agency with A.G.I.P. Mineraria, an Italian subsidiary of Ente Nazionale Idrocarbari, ${ }^{18}$ should also be noted.

Of much greater importance, however, is the settlement by arbitration of trade disputes between the traders of planned and free economies. In this connection, it is significant that the Soviet Union's recent proposal for an All-European Agreement on Economic Cooperation would provide in article nine: ${ }^{19}$

The participating States undertake to give effect to arbitral decisions in disputes arising out of commercial contracts concluded by their citizens, organizations, or institutions, where provision is made in the contract itself, or in a separate agreement expressed in the form required by the contract that disputes shall be settled by a specially or permanently constituted arbitration tribunal. ${ }^{20}$

Various countries, however, have considered this provision unnecessary, ${ }^{21}$ in as much as the Economic Commission for Europe had already studied the question of arbitration, particularly with respect to state-trading instrumentalities. ${ }^{22}$ Furthermore, the United Nations Convention on the Recognition and Enforcement of Foreign Arbitral Awards, concluded on June Io, $1958,{ }^{23}$ with the participation of several plannedeconomy countries, ${ }^{24}$ expressly provides that the Convention applies not only to awards rendered by ad hoc. appointed arbitrators, but also to "those made by permanent arbitral bodies."25

The General Conditions of Delivery of Goods between Foreign Trade Organizations of Member Countries of the Council for Mutual Economic Aid, ${ }^{26}$ in force since January $\mathrm{I}, \mathrm{I95} 8$, also provides for arbitration ${ }^{27}$ of all controversies arising out of or in

Société Kohorn v. Société Dimitrov, Trib. civ. Seine, Oct. I7, I956, [1956] Juris Classeur Periodique 9647 (note Motulsky) (Fr.).

${ }_{17}$ Art. $40-45$, the text of which appears in Hearings Before the Antitrust Subcommittee of the House Committee on the Judiciary, 84 th Cong., Ist Sess. ser. 3, pt. 2, at 1563 (1955).

${ }^{18}$ See Wall, The Iranian-Italian Oil Agreement of 1957, 7. INT'L \& CoMp. L.Q. 736, 750 (1958).

${ }^{10}$ U.N. Doc. No. E/ECE/27o, pt. I, at 9 (I957).

${ }^{20} \mathrm{Cf}$. the recent Afro-Asian Conference in Cairo, which decided to set up a permanent Afro-Asian Economic Co-operation Organization. See Journal of Commerce (N.Y.), Dec. 12, r958, p. 22, col. 4 .

${ }^{21}$ Austria, Belgium, Denmark, France, Italy, Luxembourg, Norway, Portugal, Sweden, and the United Kingdom. See U.N. Doc. No. E/ECE/270, pt. I, at $14,15,22,29,36,43,46,52,57$; id., pt. II, at $\mathrm{Ir}$ (1957).

${ }^{32}$ By the Ad-hoc Working Group on Arbitration of its Committee on the Development of Trade. See Benjamin, The Work of the Economic Commission for Europe in the Field of International Commercial Arbitration, 7 INT'L \&: CoMp. L. Q. 22 (1958).

${ }^{23}$ U.N. Doc. No. E/Conf. $26 / 9$ Rev. I (1958). See Domke, The U.N. Conference on International Commercial Arbitration, 53 AM. J. INT'L L. 4I4 (I959).

24 Albania, Bulgaria, the Byelorussian Soviet Socialist Republic, Czechoslovakia, Poland, the Ukranian Soviet Socialist Republic, the Union of Soviet Socialist Republics, and Yugoslavia.

${ }^{25}$ For more extended discussion, see text accompanying notes $8 \mathrm{I}-88$ infra.

${ }^{20}$ The Council was established in January 1949 , as a counterpart to the Marshall Plan. Its present members are the Soviet Union, Poland, Czechoslovakia, Hungary, Rumania, Bulgaria, Albania, and the German Democratic Republic.

${ }^{27}$ See Berman, Unification of Contract Clauses in Trade Between Member-Countries of the Council for Mutual Economic Aid, 7 INT'z \& CoMp. L. Q. 659, 664 (1958). 
connection with the contract, excluding "general courts," and specifying that such arbitration shall be held before the arbitration tribunal of the defendant, unless the parties agree to submit to arbitration by the tribunal of a third member-country of the Council for Mutual Economic Aid.28

Another illustration of the importance that commercial arbitration has assumed in trade between planned and free economies is the fact that a recent colloquium of lawyers, held in Rome, under the auspices of the International Association of Legal Science of UNESCO, on the Legal Aspects of Trade between Countries of Planned and Free Economies, ${ }^{29}$ also dealt with the subject. ${ }^{30}$ Among other basic problems, Western lawyers adverted to the pressure exerted by administrative authorities in countries with planned economies to compel arbitration in their own countries, thereby excluding a wider choice of available arbitration facilities, and the exclusion of foreign arbitrators from the arbitration panels in those countries. ${ }^{31}$

Clearly to understand the approach of state-trading economies to commercial arbitration, reference must be made to their historical development. ${ }^{32}$ In the twenties, the Soviet Union was the outstanding state-trading prototype. Consistent with its economic policy during that period, the Soviet Union was eager both to obtain and to grant terms and conditions favorable to all parties. It reinforced this approach with a variety of commercial treaty arrangements with European countries to ensure that any controversy would be settled in a manner consistent with Western expectations. ${ }^{\mathbf{3}}$

${ }^{28}$ Art. 65 reads: "All disputes which may arise out of or in connection with the contract shall be subject to consideration by arbitration, the jurisdiction of general courts being excluded, in an arbitral tribunal established for such disputes in the country of the defendant or, by agreement of the parties, in a third member-country of the Council for Mutual Economic Aid.

"Counter-claims shall be subject to consideration in the arbitral tribunal in which the original suit is considered.

"Disputes shall be considered in accordance with the rules of procedure which are operative in the arbitral tribunal in which the case is decided.

"The decisions of the arbitral tribunal shall be final and binding on the parties."

${ }^{20}$ See Hazard, Commercial Discrimination and International Law, 52 AM. J. INT'L L. 495 (1958); Graveson, Rome Conference on International and Comparative Law, 7 INT'L \& CoMp. L. Q. 585 (1958); Tunc, Le Colloque sur les aspects juridiques du commerce entre les pays d'économic libre, to REvus Internationale De Droit Compare 365 (1958).

${ }^{30}$ On the basis of reports by Paul L. van Recpinghen, of Belgium, Aleksander Goldstajn, of Yugoslavia, see infra note 48 , and a memorandum by Samuel Pisar, of UNESCO. See also, Tune, supra note 29, at 371; and notes by Schmitthoff, Rome Conference on International and Comparative Lasv, III Colloquium on Legal Aspects of Trade Between Countries of Planned and of Free Economies, 7 INT'L \& CoMp. L. Q. 588, 591 (1958), and $A$ New Approach to East-West Trade, 1958 J. Bus. L. I41, I46.

31 Attention was also directed to the matter of the law properly applicable in arbitration proceedings. Cf. Mezger, The Arbitrator and Private International Law, in Martin Domke (Ed.), International Trade Arbitration: A Road to World-Wide Cooperation 229 (1958).

${ }^{32}$ See Fensterwald, The Effect of State Trading Upon Arbitration, 5 Arb. J. (n.s.) 163 (1950); Hazard, State Trading and Arbitration, in Martin Domke (Ed.), International Trade Arbitration: A Road to World-Wide Cooperation 93 (1958).

${ }^{38}$ See Hilton, Commercial Arbitration in the Treaties and Agreements of the U.S.S.R., 12 DEP'T State Bull. 89o (r945); and Secretariat of the United Nations, Commercial Agreements, in Memorandum on the Soviet Doctrine and Practice with Respect to Arbitrat Procedure 15 (Doc. No. $A / C N .4 / 36)(1950)$. 
But the strengthening of its economy led the Soviet Union to the establishment of its own foreign trade arbitration body in Moscow-namely, the Foreign Trade Arbitration Commission ${ }^{34}$-whose rules of procedure were promulgated in $193^{2 . .^{35}}$ These rules have not undergone any basic change, for they are consistent with the "gradual domestication of foreign trade adjudication." Moscow, as is generally insisted upon by Soviet organizations, does not appear to be a sine qua non of foreign trade arrangements. On the contrary, commercial treaties of the Soviet Union with Denmark, of August $17,1946,{ }^{37}$ and with Hungary, of July $15,1947,{ }^{38}$ provide for the settlement of disputes by arbitration, ${ }^{39}$ but not exclusively in Moscow. And as far as American business dealings with the Soviet Union are concerned, it may be significant that as recently as $195^{8}$, an American firm was able to obtain, in a contract for the establishment of a textile plant in the Soviet Union, the insertion of an arbitration clause fixing Stockholm, Sweden, as the place of arbitration. ${ }^{40}$

This seemingly accommodating Soviet attitude deserves rather critical scrutiny, however, in light of the recent Israeli-Soviet oil arbitration, which was received quite

\footnotetext{
36 After a statute for a Maritime Arbitration Commission of the All-Union Chamber of Commerce was approved on Dec. 15, 1930. [1930] Sobranie Zakonov S.S.S.R. c. 637 (U.S.S.R.)

${ }^{36}$ Decree of June 17, 1932, [1932] Sobranie Zakonov S.S.S.R. c. 28I (U.S.S.R.). The amended rules of procedure, which were approved by decision of the Presidium of the All-Union Chamber of Commerce, Jan. 2I, 1949, appear in Economic Commission for Asia and the Far East, Conference on Trade Promotion 4 (Doc. No. Trade/59) (195I). The text of the decree and the rules may also be found in Papers on Appeal in Amtorg Trading Corp. v. Camden Fibre Mills, Inc., 277 App. Div. 53I, 100 N.Y.S.2d 747 (Ist Dep't 1950).

${ }^{30}$ Pisar, Treatment of Communist Foreign Trade Arbitration in Western Courts, in MARTIN Domke (Ed.), International Trade Arbitration: A Rond to World-Wide Cooperation Ior, I09 (1958).

${ }^{37}$ See, e.g., the Treaty of Commerce and Navigation (with Annex) Between Denmark and the Union of Soviet Socialist Republics, of Aug. I7, 1946, 8 U.N.T.S. 201, reading in its pertinent articles as follows:

"Art. x4. The settlement of any disputes which may arise in connection with contracts relating to commerce between the two Parties may be effected by means of arbitration. Each Contracting Party shall be prepared, at the request of the other Party, to enter into negotiations with a view to concluding an agreement regarding the best method of arbitration, on uniform lines, based on the principle of parity, and also regarding the method of enforcing arbitration awards. The provisions of such agreements shall have retroactive effect.

"Art. 15. Any disputes relating to commercial agreements concluded between State economic organizations of the U.S.S.R. and Danish physical or juridical persons shall, in the absence of a reservation regarding arbitration, be subject to the jurisdiction of Danish courts if the transaction was concluded in Denmark, and to the jurisdiction of the courts of the U.S.S.R. if the transaction was concluded in the Union of Soviet Socialist Republics. Nevertheless, the courts of the other Party shall have the right to determine disputes whenever their competence with regard to these disputes is definitely provided for by a condition specifically stipulated in the contract."

${ }^{38}$ Its pertinent art. 17 is translated in SECREtARIAT of THE UNITEd NATIONS, op. cit. supra note 33, at I5.

${ }^{30}$ For further instances of Soviet commercial arrangements relating to arbitration with Czechoslovakia (1947), Bulgaria (I948), and Switzerland ( 1948 ), see id. at I6.

'0 The set of circumstances surrounding the famous Lena Goldfields arbitration, under a concession agreement of April 30, 1925, which provided for appointment of arbitrators from higher academic institutions in Sweden, no longer appears pertinent. The text of the detailed arbitration clause (para. 90 of the agreement) is reprinted in the Secretariat of the United Nations, op. cit. supra note 33, at 18. Cf. Nussbaum, The Arbitration Between Lene Goldfields, Ltd. and the Soviet Government, 36 CoRnel工 L. Q. 3 I (1950).
} 
unfavorably by the business community of the Western world.11 Since this decision may constitute the context in which future arbitration arrangements with plannedeconomy trade organizations will have to be considered, some examination of its details would seem to be appropriate.

The Foreign Trade Arbitration Commission of the All-Union Chamber of Commerce of the Soviet Union forms the pattern for arbitral bodies in countries having a similar economic structure-e.g., Czechoslovakia, ${ }^{42}$ Poland, ${ }^{43}$ Bulgaria, ${ }^{44}$ Rumania, ${ }^{45}$ Hungary, ${ }^{46}$ East Germany, ${ }^{47}$ Yugoslavia, ${ }^{48}$ and Communist China. ${ }^{40}$ It consists of a panel of fifteen persons who are appointed for one-year terms. These appointees are drawn primarily from Soviet commercial, industrial, and communications organizations, although law professors having special knowledge of foreign trade are also frequently included. Each party to a dispute selects an arbitrator from the panel. In the event that these two are unable to reach agreement, they select a third arbitrator from the panel; and if they cannot agree upon one, the Chairman of the Commission makes the selection. There is no appeal from the awards of the

11 Infra note 57.

See Landa, Note on Court of Arbitration of the Chamber of Commerce of Czechoslovakia, 83 Journal Du Droit Internationaz 452 (France 1956). The Decree of the Ministers of Forcign Trade and of the Interior of June 30, I952, on the Organization of a Czechoslovakian Chamber of Commerce and the statute and arbitration rules of the Chamber were considered by the Swiss Federal Tribunal in Linga v. Baumgartner \& Co., A.G., Bundesgericht, Feb. 12, 1958, 84(I.) Entscheidungen des Schweizerischen Bundesgerichtes [hereinafter S.B.G.] 39 (Swit.). For an analysis of these rules, see AD Hoc Working Group of Arbitration Committee on the Development of Trade, Economic Commisston for Europe, Handbook of National and International Institutions Active in the Field op International Commercial Arbitration 93 (Doc. No. Trade/WPi/15, Rev. I) (1958) [hereinafter referred to as HANDBOOK].

${ }^{4}$ The Court of Arbitration of the Polish Chamber of Foreign Trade was established by para. 4(14) of the Decree of the Ministers' Council of September 28, r949, to develop and intensify the commercial relations of Poland with foreign countries. See Arbitration Organized by the Polis/s Chamber of Foreign Trade, Polish Foreign Trade, Sept.-Oct. 1950, p. 68 . Arbitral decisions are published in Orzecznictwo Sadow Polskich I Komisji Arbitrazowych [Decisions of the Polish Counts and of thib Arbitration Commission] (1957). Cf. Handboox I57.

"See Sipkov, Foreign Trade, Chamber of Commerce, and Foreign Trade Arbitration Commission under Communist Government, in U.S. Library of Congress Mid-European Law Projecr, Highliguts of Current Legislation and Activities in Mid-Europe 423, 432 (1956). Cf. Handdod 88.

${ }^{46}$ On the Foreign Trade Arbitration Commission of the Rumanian Chamber of Commerce, see HaND. BOоK 162.

${ }^{48}$ On the Arbitration Court of the Hungarian Chamber, see id. at 135 .

"See Schiedsgerichtsordnung des Schiedsgerichts bei der Kammer fuer Aussenhandel der Deutschen Demokratischen Republik (1957). For an analysis of the rules of the Arbitration Court attached to the Chamber of Commerce of Forcign Trade, see HandBook 189.

${ }^{48}$ See Rules of the Court of Foreign Trade Arbitration of the Chamber of Commerce of Yugoslavia, Official Gazette of the Federated People's Republic of Yugoslavia, No. 26, March 28, 1947; Rules of Conciliation, Nov. 24, 1948, Commercial Information of the Chamber of Commerce, No. 3, 1949, p. 24. Cf. Handbook 2r2. See also Goldstajn, Arbitration and Arbitration Procedure in Yugoslavia, 2 Ax. J. CoMP. L. 588 (1958), and Submission to Arbitration of Disputes with a Foreign Element, 5 JugosLovenskA Revija za Medunarodno Pravo il8 (1958); New Rules for Foreign Trade Arbitration (Yugoslavia), I959 J. Bus. L. 198.

${ }^{10}$ A Foreign Trade Arbitral Tribunal of the China Committee for the Promotion of International Trade was established by resolution of the Administrative Council of the People's Republic on May 6, 1954 . Provisional rules of procedure ( 38 articles) were adopted on March 31, 1956. A German translation of the resolution and the rules appears in 3 Osteuropa Rechr I2I (I957). 
Commission..$^{50}$ In 1941, an official report was issued, encompassing about five years work of the Foreign Trade Arbitration Commission, either in full reports or in abstracts, covering twenty-nine cases decided during that period. These cases concerned disputes between Soviet state-trading organizations and Belgian, Canadian, Dutch, Egyptian, English, French, German, Greek, Norwegian, and Swedish parties. ${ }^{51}$ It was before this Foreign Trade Arbitration Commission that the IsraeliSoviet oil arbitration took place.

In I953, two Israeli companies, Jordan Investments, Ltd., and Delek Israeli Fuel Corporation, entered into contracts with a Soviet state-trading agency, Soiuznefteksport, for the purchase of petroleum products, to be delivered f.o.b. Black Sea ports. Similar contracts were subsequently signed for the purchase of petroleum products during 1957 and 1958. All of these contracts were concluded in Moscow and contained the usual clause providing for arbitration in Moscow. ${ }^{52}$ On November 6, 1956, after Israeli troops had entered the Sinai Peninsula, Soiuznefteksport advised the Israeli companies that the Ministry of Foreign Trade had withdrawn export licenses for the balance of petroleum products to be delivered in 1956 , and that no export licenses would be granted for deliveries in 1957 and 1958 . Soiuznefteksport then canceled the contracts, relying on a force majeure clause excusing a nonfulfillment which "rests on any circumstance that is beyond the control of the defaulting party." The Israeli companies were thus obliged to find and transport petroleum from other sources and suffered heavy losses as a result.

In October 1957, one of the companies, Jordan Investments, Ltd., invoked arbitration in Moscow, demanding damages of $\$ 2,396,440$. Thirteen hearings took place between January I9, I957 and June 19, I958, before three arbitrators, all members of the Foreign Trade Arbitration Commission. Within an hour of the close of the last hearing, ${ }^{54}$ the arbitrators dismissed the Israeli company's claim. The motivated award was made and signed on July 3, I958.

${ }^{50}$ Unlike the awards of the Maritime Arbitration Commission, from which an appeal lies to the Supreme Court of the Soviet Union, which may set an award aside and remand the case to the Commission "if the existing laws are contravened or wrongly applied in the award." See art. 24 of the rules of procedure of the Foreign Trade Arbitration Commission, supra note 35 .

${ }^{51}$ See Secretariat of the Unrred Nations, op. cit. supra note 33, at I8. See also Rashba, Settlement of Disputes in Commercial Dealings with the Soviet Union, 45 CouvM. L. Rev. 530 (I943); Egerhardt Pfuhl, Die Aussenhandels-und Seearbitrage der U.S.S.R. (I953); Leo A. Yaresh, ArbiTRATION IN ThE Soviet Union (Research Program on the U.S.S.R.-East European Fund, Inc., Series No. 52, 1954). For a further survey of other arbitral bodies in countries with planned economies-e.g., Hungary, Bulgaria, and Rumania - see Benjamin, Aperģu des institutions arbitrales de l'Europe de l'est qui exercent une activité dans le domaine de l'arbitrage commercial international, in Y957 REVUE DE I'ARBITRAGE II $4 ;$ I958 id. at 2.

DS The clause reads as follows: "Any disputes which may arise out of the fulfilment of the present contract or in connection with it are to be settled by the Foreign Trade Arbitration Commission of the U.S.S.R. Chamber of Commerce in Moscow in conformity with the rules of said Commission. The decisions of said Commission are to be final and binding upon both parties."

${ }^{53}$ Clause 7 of the contract provides for the discharge from liability for nonperformance of the contract if such nonperformance is due not only to causes of force majeure enumerated in the clause-e.g., disasters of nature, blockades, strikes, etc.- "but also to any other cause beyond the control of the defaulting party."

"This fact of only "about forty minutes" of deliberation was expressly mentioned in the N.Y. Times, June 20, I958, p. I, col. x, p. 2, col. 5. Case No. I6/1957. 
Here is a situation where the Soviet Government had instructed one of its instrumentalities to renege on its contractual commitments. Soiuznefteksport did not protest the order. $\mathrm{U}_{\mathrm{P}}$ to this point, the situation would seem to be one that might have occurred in any other country. The familiar pattern was upset, however, when the governmental instrumentality appeared as a party before an arbitral body which consisted solely of arbitrators bound to uphold an official policy which was implicit in the instrumentality's action.

Although this is not the place to review the arbitration award on its merits-i.e., whether, even under the applicable Soviet law, ${ }^{55}$ a trading organization which is part of the Government, cannot be held responsible for the acts of the Governmentseveral points must be noted. Article twenty-one of the rules of procedure of the Foreign Trade Arbitration Commission provides that each party "must prove the circumstances which it refers to as grounds for its claims or objections." Yo Yet, the Commission prevented the lawyers representing the Israeli company from submitting this essential proof. The Israeli counsel claimed that the seller's duty to carry out the contract under any circumstances is an accepted rule of Soviet law and, when the Soviet defense counsel denied that statement, asked permission to call a Soviet legal authority to so testify. The Commission, however, refused this request, nor would it allow any Soviet witnesses to testify on questions of fact, especially as to whether the export organization had tried to save the contract, or on the prevailing Soviet practice for granting export licenses.

Indeed, the arbitration proceedings per se-apart from the award itself dismissing the claim-evoked highly critical comment throughout the world; ${ }^{57}$ and it raises a number of vital questions concerning Soviet foreign trade arbitration in general. ${ }^{58}$

The first question is whether arbitration tribunals of countries with planned economies are really impartial bodies, willing and able to decide issues on their merits, or whether they are, in fact, only the mouthpieces of their governments. In other words, is there the probability or even the possibility that a fair determination adverse to some national policy of the arbitrators' country may be reached? A presumption of such impartiality not only has colored the prevailing opinion of

${ }^{25}$ Cf. Agarkov, The Debtor's Discharge from Liability When Performance Is Impossible, 29 J. Comp. LEG. \& INT'L L. (3d ser.) 9 (1947).

${ }^{5 B}$ See supra note 35 .

${ }^{67}$ See, e.g., The Times (London), June 30, 1958, p. 7; Financial Times (London), June 27, 1958, p. 8; Manchester Guardian, June 27, 1958; Journal of Commerce (N.Y), July 3, 1958, p. 6; Berlingske Tidende (Copenhagen), June 23, 1958; Nieuwe Rotterdamsche Courant (Rotterdam), July ro, 1958; Neue Zuercher Zeitung (Zurich), July 5, r958; Die Welt (Hamburg), June 24, 1958; Aussenwirtschaftsdienst des Betriebs-Beraters (Heidelberg), Sept. 1958, p. 187; id., Feb. 1959, p. 36.

${ }^{58}$ See the recent German language literature on Soviet foreign trade arbitration, and references thercin to further source material. E.g., Awjerino, Das Recht der Azssenhandelsgeschaefte der Socvietunion, I Recht der Internationalen Wirtschaft I8I, I84 (1955); I Carl-Hans Buetow, Das Gegenwaertige INNERSTAATLICH GEREGelte AUSSENhaNDELSRECHT DER UDSSR UNTER BERUECKSICHTIGUNG DER ZWISHENSTAATLICHEN Vertraege 232 (1956); Pfuhl, Gewaehrleistung und Garantie im zevischenstaatlichen Aussenhandel des Ostblocks, 2 ReCHT IN OsT UND WeST 116 (1958). 
Western legal writers, ${ }^{59}$ but has also been judicially recognized. ${ }^{60}$ Thus, the New York Court of Appeals, in Amtorg Trading Corp. v. Camden Fibre Mills, Inc., staying a court action instituted by a Pennsylvania corporation against the New York agency of the Soviet Government until arbitration had taken place, said: "Camden chose to do business with Amtorg and to accept as one of the conditions. imposed, arbitration in Russia; it may not now ask the courts to relieve it of the contractual obligation it assumed." expressly reserved to the Pennsylvania corporation the right to take "appropriateaction should the arbitration in fact deprive it of its fundamental right to a fair and" impartial determination." "'2

In Linga v. Baumgartner \& Co., A.G., ${ }^{* 3}$ the Swiss Federal Tribunal, in a decision of February 12, I958, reversed a decision of March 15, I957 of the Zurich appellatecourt, which had confirmed a lower court, ${ }^{64}$ and granted execution of an arbitral' award rendered under the rules of the Court of Arbitration of the Czechoslovakian Chamber of Commerce in Prague. Neither the composition of the tribunal of exclusively national (Czechoslovakian) arbitrators nor the proceedings themselves was: held sufficient, under the Swiss-Czechoslovakian Treaty concerning the Recognition: and Enforcement of Judicial Decisions of December 21, $1926{ }^{65}$ and the Geneva Convention on the Execution of Foreign Arbitral Award of September 26, 1927, ${ }^{60}$ to deny enforcement on public policy grounds. ${ }^{67}$ The court, in fact, expressly refuted the challenge that in view of the state monopoly of foreign trade in Czechoslovakia, the Chamber of Commerce could no longer be considered a neutral institu-. tion, because it has primarily to serve the interests of the state. Holding that the-

${ }^{50}$ Sec, e.g., Schaer and Luther, Bericht ueber die Durchfuehrung eines Schiedsverfahrens vor der Aussenhandels-Arbitragekommission der UdSSR in Moskan, 2 RECHT DER INTERNATIONALEN WIRTSCHAFT 75 (1956); von Beringe, Rechtsfragen bei Handelsgeschaeften mit der Sowjetunion, II DER BETRIEB 859. 862 (r958).

${ }^{\circ} \mathrm{Sec}$ Pisar, Soviet Conflict of Laws in International Commercial Transactions, 70 HARv. L. REv. 593, 6II (1957), and Treatment of Communist Foreign Trade Arbitration in Western Courts, in MarTiN Domke (Ed.), International Trade Arbitration: A Road to World-Wide Cooperation ioi (i958). ${ }^{01} 304$ N.Y. 519, 521, I09 N.E.2d 606, 607 (1952).

Q2 Ibid., referring to the N.Y. Civil Practice Act, art. 146r-62.

${ }^{03}$ Bundesgericht Feb. 12, 1958, 84 (I.) S.B.G. 39 (Swit.).

of The unpublished decision of the appellate court is noted by Pisar, Treatment of Communist Foreign Trade Arbitration in Western Courts, in Martin Domke (Ed.), Internationaz Trade Arbitration: A. ROAD TO WORLD-WIDE COOPERATION IOI, IO5 (1958).

oi i2 Amitziche Sammlung der Bundesgesetze und Verordnungen der Schweizerischen EidgenOSSENSCHAFT 348 (I926).

${ }^{\circ 0} 92$ L.N.T.S. 30I; text also in Martin Domere (Ed.), International Trade Arbitration: A Road, to WORLd-Wide CoOperation 285 (1958).

${ }^{07}$ The challenge was based on earlier Swiss decisions that awards are not to be enforced if the. arbitral tribunal lacks independence (Unbefangenheit), or if one party has a privileged position (Vorzugsstellung) before it, Lunesa Watch S. A. v. Federation Suisse des Associations de Fabricants d'Horlogerieund Konsorten, Bundesgericht, Dec. 7, 2955, 8I (I.) S.B.G. 32r, 33I; and that this principle was also. applicable to foreign awards. Biedermann v. Brodr. Justesen, Bundesgericht, May I7, 1950, 76 (I.) S.B.G. 121, 128. See Guldener, Die Gerichtsbarkeit der Wirtschaftsverbaende, and Piaget, Les jurisdictions institutées par les associations economiques, in ZEITSCHRIFT FUER SCHWEIZERISCHES RECHT (N.F.) pt. 2, at 208a, 27ra (r952). 
law of the state where the arbitration proceeding was held is applicable, the court said (translation):

It would be going too far to admit, for the determination of international commercial controversies, only arbitral tribunals which are composed either evenly of nationals of the states of both parties or of the nationals of other countries.... It is not appropriate and not reconcilable with the principle of good faith to submit to the arbitral body of a foreign state with different political and economic conditions and then subsequently contest the impartiality of that arbitral body because of those conditions. ${ }^{08}$

The composition of planned-economy arbitral tribunals has, indeed, been the primary basis for challenging submissions thereto. While it is true that representation of foreign parties by foreign lawyers is allowed ${ }^{60}$ and no refusal of visa for entry and sojourn in the country has yet been reported, ${ }^{70}$ the arbitrators themselves have exclusively to be citizens of that country. ${ }^{71}$ Nor is there any sign that this shortcoming will easily or quickly be remedied. Safeguards such as those included in arbitration rules of the International Chamber of Commerce, ${ }^{72}$ the American Arbitration Association, ${ }^{73}$ or the Japan Commercial Arbitration Association, ${ }^{74}$ which require that a single arbitrator or the chairman of the arbitration board be of a nationality other than that of either party to the proceedings, will not, in all probability, be adopted.

The next question, then, is whether a wider choice of arbitration facilities, in tribunals other than those of the planned-economy country-i.e., in the country of the other party or in a third (neutral) country-would be feasible. As noted above, a recent trade agreement between a Soviet organization and an American firm pro-

${ }^{88}$ Similarly, challenges of the enforcement of awards of the Foreign Trade Arbitration Commission in
Moscow have been refuted by Turkish and Belgian courts. See Pisar, Soviet Conflict of Latus in Inter-
national Commercial Transactions, 70 Harv. L. Rev. 593, 612 nn. 54,55 (I957).
${ }^{\circ 8}$ Art. 20 of the rules of procedure of the Foreign Trade Arbitration Commission, supra note 35 ,
provides that the parties may conduct their cases before the Commission "cither personally or through
their representatives appointed by them at their own discretion; such representatives may be forcign
citizens."

${ }^{70}$ Hazard, Soviet Commercial Arbitration, I INT'L ARB. J. 96 (1946), observes that "representatives of the American principal may expect to obtain a visa for travel to the U.S.S.R. in connection with any hearing relative to the dispute."

${ }^{7}$ E.g., art. 2(3) of the Rules of the Court of Foreign Trade Arbitration of the Chamber of Commerce of Yugoslavia (1947) provides: "Only citizens of Yugoslavia may be elected to the post of an arbitrator." For further references to arbitration tribunals of planned-economy countries, sec Pisar, Treatment of Communist Foreign Trade Arbitration in Western Courts, in Martin DoMKe (Ev.), INternational Trade Arbitration: A Road to World-Wide Cooperation 101, 103 n. 10 (1958); for statutory law of other countries excluding foreigners as arbitrators, see PIETER Sandens (ED.), Introduction to International Commercial Arbitration 15 (1956).

${ }_{72}$ Art. $7(3)$ of the rules (in effect since June 1, 1955) provides: "Sole arbitrators and third arbitrators must be nationals of countries other than those of the parties."

${ }^{73} \S x_{5}$ of the rules (in effect since September $x, 1954$ ) provides: "If one of the partics is a national or resident of a country other than the United States, the sole Arbitrator or the third Arbitrator shall, upon the request of either party, be chosen or appointed from among the nationals of a country other than that of any one of the parties."

${ }^{74}$ Art. I5 (a) of the rules (in effect since March I5, 1950) provides: "In a case where one or more Arbitrators shall be appointed, the sole Arbitrator or the third Arbitrator shall, upon the request of either party to the dispute, be chosen from among the nationals of a country other than that of any one of the parties." 
vided for arbitration in Sweden. ${ }^{75}$ Furthermore, the service agreement of the AllUnion Chamber of Commerce in Moscow with the Japan Commercial Arbitration Association of May 27, $1957,{ }^{76}$ provides that arbitration between Soviet foreign trade organizations and Japanese physical and juridical persons shall be had in the country of the defendant in a dispute or discord "which may arise from or in connection with this contract."77 Moreover, countries with planned economies do allow agreement for arbitration of their commercial disputes with foreign traders in the country of the latter. $^{78}$ Thus, Yugoslav trade organizations in the recent past have repeatedly used the facilities of the American Arbitration Association for arbitration in New York City. ${ }^{79}$

Despite many objections to the arbitration tribunals of countries with planned economies, the fact that these institutions are internationally recognized bodies became unmistakably evident in the deliberations of the I958 Conference on International Commercial Arbitration, held at the United Nations. In discussions concerning a Draft Convention on the Recognition and Enforcement of Foreign Arbitral Awards, in which representatives of eight countries with planned economies participated, ${ }^{80}$ it was stated that permanent arbitration bodies, such as exist in those countries, should have the same standing as other ad hoc established arbitration tribunals of Western systems. This was decided by the Conference with respect to the most important aspect of commercial arbitration-the enforcement of awards rendered in a country other than that where execution is being sought.

The provision in article $I(2)$ that the convention embrace "not only awards made by arbitrators appointed for each case but also those made by permanent arbitral bodies to which the parties have submitted," was first suggested at the Conference by the Czechoslovakian representative; ${ }^{81}$ but it was contested by the Israeli representative, who considered it superfluous, observing that "if the procedure followed by the permanent bodies was genuinely arbitral ... there could be no such arbitration in a tribunal imposed by one State alone."82 The Italian representative correctly noted that the crucial question was not "whether the body was permanent or specially appointed, but whether there was an element of compulsion in the submission,"83 a viewpoint supported by the French representative, who characterized awards made by such bodies to which the parties were compelled to have recourse "the same as

${ }^{25}$ See text at note 40 supra.

${ }^{70}$ See Japanese Annual of International Law i67 (1957).

${ }^{77}$ A similar provision appears in the arbitration clause in contracts under the Council for Mutual Economic Aid. See supra note 28.

${ }^{78}$ See BuETow, op. cit. supra note 58 , at 233 .

${ }^{70}$ E.g., Centroprom Export and Import Corporation. Cf. Goldstajn, Submission to Arbitration of Disputes with a Foreign Element, 5 Jugoslovenska Revija za Medunarodno Pravo xi8, I22 (I958).

${ }^{80}$ See supra note 23 and 24 .

${ }^{81}$ U.N. Doc. No. E/CONF. 26/SR.7, at 3 (1958), presenting an amendment, U.N. Doc. No. E/CONF. 26/L/10 (1958), based on the report of the Ad-hoc Committee on the Draft Convention, of March 28, 1955. U.N. Doc. No. E/2704, para. 25 (I955).

${ }_{82}$ U.N. Doc. No. E/CONF. 26/SR. 8, at 2 (1958).

${ }^{83}$ Ibid. "If the parties were bound to refer their disputes to that body, the procedure was of a judicial nature." 
judicial decisions." ${ }^{84}$ Although a Belgian amendment to insert "voluntarily" before "submitted"85 was accepted by the Conference, ${ }^{86}$ the Drafting Committee in its report questioned the need for this word, ${ }^{87}$ and it was, in fact, deleted from the final text of the Convention. ${ }^{88}$ Thus, it appears that permanent arbitration bodies in countries with planned economies, though state institutions with arbitrators appointed by state organs, are internationally recognized and accepted.

There is no doubt that the settlement of disputes arising out of state-trading transactions-and not only with countries with planned economies-should not be left to diplomatic negotiation, but should be administered by arbitration tribunals. Nevertheless, the recent Israeli-Soviet oil arbitration cannot easily be ignored. It is true that ${ }^{80}$

... the general trend of commercial law everywhere is to move away from the restrictions of national law to a universal international conception of the law of international trade. New international conventions, universal commercial practices indicate the growing horizon of modern commercial law.

Still, at this juncture, no generalization can be ventured in the use of arbitration for the settlement of particular state-trading disputes. The parties must weigh the advantages and disadvantages. In short, they must consider "the domestic arbitral jurisprudence; the corporate or non-corporate nature of state trading organizations; the overall extent of state trading in a country's economy; and the world trade position and bargaining power of the state trader." ${ }^{300}$ However, the legal uncertainty still prevailing in state-trading relations can hardly be better illustrated than by the recent Argentine Petroleum Nationalization Bill of November 12, 1958, ${ }^{01}$ which reaffirms the autonomy of Yaciimientos Petroliferos Fiscale, the state agency, and which prohibits, in its article four, the signing of any contract, "whatever its denomination, containing clauses prejudicial to the Nation's economic independence or which might prejudice in any other manner the Nation's self determination."

${ }^{81} I d$. at 4 .

${ }^{85} \mathrm{Id}$. at 5 .

${ }^{80} 25$ votes for, 8 against, with 6 abstentions, after devoting the entire plenary session of May 26 , I 958 to the debate on that question only. Id. at 8 .

87 Id. SR. 23, at 4 .

${ }^{88} 24$ votes for, 2 against, with 7 abstentions. Id. at 6 .

${ }^{89}$ Clive M. Schmimthoff, Modern Trend in English Commercial Law 354 (1957), quoted with approval by Goldstajn, Submission to Arbitration of Disputes With a Foreign Element, 5 JugosLovenskA Revija za Medunarodno Pravo ri8, 123 (1958).

${ }^{90}$ Fensterwald, supra note 32 , at 168 .

${ }^{91}$ Law No. 14,773, of November 12, 1958, translated in Foreign Commerce Weekly, Dec. 27, I958, p. 5 . 